\section{On the future contents of a small journal of histochemistry}

\author{
C. Pellicciari \\ Dipartimento di Biologia e Biotecnologie \\ "Lazzaro Spallanzani”, Università \\ di Pavia, Italy
}

\section{Abstract}

In the last three years, more than 70,000 scientific articles have been published in peer reviewed journals on the application of histochemistry in the biomedical field: most of them did not appear in strictly histochemical journals, but in others dealing with cell and molecular biology, medicine or biotechnology. This proves that histochemistry is still an active and innovative discipline with relevance in basic and applied biological research, but also demonstrates that especially the small histochemical journals should likely reconsider their scopes and strategies to preserve their authorship. A review of the last three years volumes of the European Journal of Histochemistry, taken as an example of a long-time established small journal, confirmed that the published articles were widely heterogeneous in their topics and experimental models, as in this journal's tradition. This strongly suggests that a journal of histochemistry should keep its role as a forum open to an audience as broad as possible, publishing papers on cell and tissue biology in a wide variety of models. This will improve knowledge of the basic mechanisms of development and differentiation, while helping to increase the number of potential authors since scientists who generally do not use histochemistry in their research will find hints for the applications of histochemical techniques to novel still unexplored subjects.

\section{Introduction}

Especially in the last few years, the number of open-access journals in the biomedical field has dramatically increased, ${ }^{1}$ and this tendency is still continuing. As a consequence, when cell and tissue biology is considered, new competitors are adding every day to the traditional journals on histochemistry. Most of the new openaccess journals are not yet indexed, and their quality and peer-reviewing strictness are questionable; this surely makes the journals with established reputation still preferable for scientists, although special offers for manuscript publication are often proposed by the new jour- nals which may be appealing in the present situation of generalized grant shortening.

Under this scenario, especially the small journals should probably reconsider their scope and strategies, in the attempt to preserve their readership and the possibility to receive a sufficient number of good manuscripts to be selected for publication. Survival of a journal depends on the capability of saving and extending its authorship, and to this aim the present trends in the application of histochemistry should be considered while taking into account the authors' interests as they result from the articles published in recent years.

\section{Histochemistry in the biomedical field in recent years}

The title of the last $54^{\text {th }}$ Symposium of the Society for Histochemistry held in Vienna, last September 5-8, 2012 (http://www.histochemistry54.eu/) was Imaging development: tracking cells in order and disorder, the main topic being stem cell commitment and differentiation during normal development of invertebrate and vertebrate taxa as well as aberrant differentiation and de-differentiation under pathological conditions. The goal of understanding normality through the integrated analyses of structural, molecular and dynamic features of tissues and cells was one of the take-home messages of this Conference, thus underlying the unique opportunities provided by the histochemical approach in the attempt to describe basic mechanisms of cell proliferation, differentiation and death during normal development or under physiological conditions, and to discriminate altered pathological traits: this may be achieved only through the application of refined histochemical methods and novel microscopy techniques to detect specific molecular components at high resolution, as several presentations in the Symposium have actually demonstrated.

Biological processes in tissues, cells and subcellular compartments can only take place in a spatially organized environment, and an accurate description of these phenomena may be obtained by correlating the structural features to the composition and location of molecular markers: to this purpose, the microscopical and histochemical approach is definitely irreplaceable especially when the biological samples under investigation are characterized by an intrinsically complex and heterogeneous organization at the tissue, cell or organelle levels. This is one of the raisons why Histochemistry has been increasingly used in the biological research becoming a common tool for scientists in a wide variety of disci-
Correspondence: Prof. Carlo Pellicciari, Dipartimento di Biologia e Biotecnologie "Lazzaro Spallanzani", Università di Pavia, via A. Ferrata 9, 27100 Pavia, Italy.

E-mail: pelli@unipv.it

Key words: Basic and applied histochemistry

Received for publication: 29 November 2012. Accepted for publication: 4 December 2012.

This work is licensed under a Creative Commons Attribution NonCommercial 3.0 License (CC BYNC 3.0).

CC Copyright C. Pellicciari, 2012

Licensee PAGEPress, Italy

European Journal of Histochemistry 2012; 56:e51 doi:10.4081/ejh.2012.e51

plines investigating biology from the molecular to the organism level: this is apparent if we consider that, in the last three years, more than 70,000 scientific articles have been published in peer reviewed journals on the application of histochemistry in the biomedical field, with more that 22,000 articles per year during the 2000-2012 period (source: http://www.ncbi.nlm.nih.gov/pubmed/).

Thus histochemistry proves to be a still active, productive and innovative discipline with broad application not only in basic biological research, but also in the diagnostics of human and animal diseases where histochemistry continues to be a reliable and sometimes unique tool integrating and validating the results of the widely used molecular bioassays. ${ }^{2}$ Consistently, the journals reporting articles where histochemistry is exploited have progressively increased in number, over the last decades; however, the journals strictly devoted to histochemistry are the most appropriate and up-to-date source of information both for the novel technical achievements and the application on new biological models. In addition, a survey, over a given timespan, of the articles' contents may suggest the recent tendencies in histochemists' interests and help to envisage their future evolution: a journal which traditionally covers a broad range of research subjects may represent a simplified model for such a review.

\section{A survey of the recent contents of a long-time established histochemical journal}

The European Journal of Histochemistry is an example of a long-time established journal which has been uninterruptedly published 
since 1954: as the official organ of the Italian Society of Histochemistry, since its very first issue it publishes reports on investigations by scientists from all over the world, on a wide variety of biological and biomedical subjects. In the present survey, the 130 articles issued in the last three years have been considered, and their contents compared with those published in the first ten years of publication of the journal (1954-1963) and in the ten-year period 2001-2009. The articles published in 2010-2012 have been classified into the few main topics, as selected in a previously published comment, ${ }^{3}$ namely Animal biology \& veterinary medicine, Human biology \& histopathology, Methods \& techniques, Stem cells \& development, Neurobiology \& endocrinology, Cell nucleus, Muscle tissue, Connective tissue, Cell proliferation \& death, Plant cell biology (Figure 1 reports the distribution of the papers in the different subjects).

In the last three years, more than $45 \%$ of the articles fall into the first two categories, confirming the trend of histochemical research especially in recent years:2,3 actually, more than $90 \%$ of the scientific articles applying histochemistry or immunohistochemistry that have been published in peer reviewed journals since January 2010 to date, concerned pathological conditions in humans or other vertebrates (source: http://www.ncbi.nlm.nih.gov/ pubmed/).

In the last-three-years sample from the European Journal of Histochemistry, several articles concerned the search for one or more diagnostic and prognostic indicators specifically marking a given disease, ${ }^{4-15}$ but other were focussed on experiments aimed at identifying the molecular bases of the pathogenetic process, ${ }^{16-20}$ or at assessing the metastatic potential of tumour cell populations, ${ }^{21,22}$ or at describing the effects of therapeutic interventions. ${ }^{23-27}$ Most of these studies were performed by light (essentially conventional or confocal fluorescence) microscopy, but electron microscopy and ultrastructural immunohistochemistry has also been used for investigating functional changes in cells from different tissues or under different experimental conditions. ${ }^{28-37}$ To localize specific nuclear components, multiple immunohistochemical techniques and quantitative analyses of the immunogold labelling have been utilized, ${ }^{38}$ and this approach proved to be especially appropriate to detect the alteration in transcription and splicing which characterizes specific diseases. $^{24,31,39}$

Actually, the changes in the organization and molecular composition of nuclear domains are well established markers of changed cellular metabolism or cell dysfunctions related to pathological phenotypes. ${ }^{40,41}$ The application of techniques of nuclear histochemistry in paral-

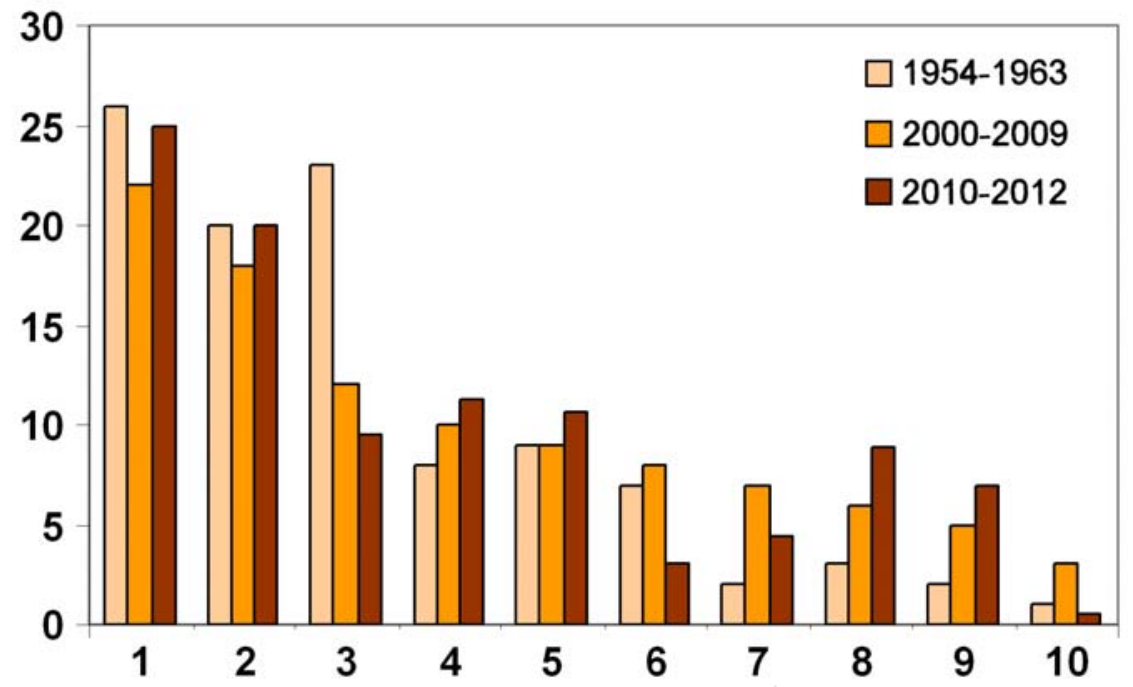

Figure 1. Percentage of the articles on different subjects published in the European Journal of Histochemistry during the ten-years periods, 1954-1963 and 2001-2009, and in the last three years, 2010-2012. The article subjects reported in the abscissa are as follows: 1. Animal biology \& veterinary medicine; 2 . Human biology \& histopathology; 3 . Methods \& techniques; 4. Development \& stem cells; 5. Neurobiology \& neuroendocrinology; 6. Cell nucleus; 7. Muscle tissue: 8 . Connective tissue, bone $\&$ cartilage; 9 . Cell proliferation \& death; 10. Plant cell biology.

lel with biomolecular methods allowed to demonstrate basic mechanisms of some muscle diseases characterized by altered organization of nuclear structures, ${ }^{29,39}$ and revealed intriguing similarities in the origin of muscle atrophy in sarcopenia and myotonic dystrophy: this was demonstrated by studies on skeletal muscle ex vivo as well as on cultured myoblasts and myotubes in vitro. ${ }^{31,37,42}$ Interesting results have also been reported on the expression of different cytoplasmic or nuclear proteins of mammalian myocytes and heart muscle cells during differentiation or aging, ${ }^{43}$ or under physiologically or experimentally induced conditions of inactivity, physical exercise or oxidative stress. ${ }^{33,44-46}$

Several articles have also been published on normal human or animal cytology and histology: though being sometimes descriptive in nature (this is especially true for non-human animal taxa), ${ }^{47-66}$ their scope was often to identify specific features within heterogeneous human tissues or cell populations, in view of possible applications in therapy or regenerative medicine. ${ }^{30,32}$ Electron microscopy and ultrastructural cytochemistry have largely been used for such studies, confirming the importance of associating morphostructural evidence and molecular composition at high-resolution.

Most of the investigations performed on non-human vertebrates were aimed at monitoring the effects of different kind of stress (such as intoxication, infection, environmental pollution, or ischemia/reperfusion) through the histochemical detection of altered organization or function in different organs and tissues. $^{27,28,67-75}$

Developmental (including reproductive) biology received increasing interest, in the last three years, with papers devoted to the reproductive system, ${ }^{76,77}$ with special attention to the expression of hormones or hormone receptors $; 5,78$ articles have been published on oocyte differentiation, elimination in vivo, and cryopreservation,,$^{34,35,79}$ or the expression of growth factor or proliferation/differentiation markers during development of humans ${ }^{80,81}$ and nonhuman vertebrates..$^{49,82-86}$ It is worth noting that several articles were especially focussed on neurobiology and endocrinology during embryogenesis ${ }^{87-89}$ post-natal development ${ }^{90-92}$ or aging. ${ }^{93}$ Most of the papers on stem cell biology concerned precursors of mesenchymal origin from the adipose tissue,,$^{30,32}$ cartilage ${ }^{86,94}$ or bone, ${ }^{95,96}$ the attempts to elucidate some of the mechanisms responsible for their commitment and differentiation in vitro were often aimed at designing suitable strategies for their application in tissue engineering or plastic and reconstructive medicine. ${ }^{30,32,94,96}$ In this perspective, it becomes primarily important to discriminate cells in the different phases of proliferation, differentiation, aging and death, through specific molecular markers: multiple immunocytochemical techniques were widely applied to this aim..$^{24,31,38,43,45,97-99} \mathrm{~A}$ manuscript only was devoted to plant cell development, ${ }^{100}$ and this confirms that histochemistry is still relatively poorly used by plant biologists in 
their research: actually, in the last three years, only 30 papers have been published, in which histochemical techniques have been used in investigations on plant cell biology (source: www.scopus.com). In recent years, connective tissues and, in particular, bone and cartilage have become increasingly popular subjects for the authors of the European Journal of Histochemistry. ${ }^{94,101-107}$ Histochemistry proved to be especially suitable for investigating structure and function of the articular disc under different experimental and pathological conditions, with special reference to the temporomandibular joint. $86,97,102,104,105,108,109$ In addition, two supplements have been published, collecting the abstracts of the XXXI and XXXII National Meeting of the Italian Society for the Study of Connective Tissues (SISC). ${ }^{110,111}$

Notes on methods and techniques have been fewer than in the previously considered periods: though being more addressed to the application of established techniques in cell and tissue biology, the authors of the European Journal of Histochemistry did however pay attention also to setting up innovative tools ${ }^{112-117}$ or implementing conventional methods. ${ }^{118-124}$ Cytogenetic techniques have been used to identify repetitive DNA sequences in the genome of humans and other vertebrates. ${ }^{121,125,126}$

\section{Concluding remarks}

In a review article ${ }^{127}$ summarizing the papers published in Histochemistry and Cell Biology during 2011, Stefan Huebner and Athina Efthymiadis underlined that the studies published in that journal represent once more a manifest of established and newly sophisticated techniques being exploited to put tissue- and cell type-specific molecules into a functional context.

This may probably be regarded as common aim for most of the journals which are chiefly devoted to histochemistry, but it is worth considering that peculiarities may also exist for each journal which essentially relate to its tradition. The subjects as well as the methods and techniques used in the recently published articles thus become an obvious filter for the authors in selecting the manuscripts to be submitted. As a consequence, the readership too is somewhat selected in a sort of self-propagating circle, which may become either virtuous or vicious for the future of a given journal.

No doubt, the primary goal of any journal is to extend its visibility and impact on the scientific community through the publication of high quality manuscripts; this may be reached by preferentially selecting the most appropriate hot-topics, excluding or reducing publica- tion of papers on subjects whose interest is restricted to a relatively low number of scientists. However, a journal of histochemistry should also keep its role as a forum open to an audience as wide as possible, and this is especially appropriate for those small journals such as the European Journal of Histochemistry- which are traditionally opened to an extensive choice of research topics. Presenting data on cell and tissue biology in a wide variety of models will help to increase our knowledge of the basic mechanisms governing development and differentiation under normal and pathological conditions; this will also help to increase the number of potential authors since scientists who generally do not use histochemistry in their research will find hints for the applications of histochemical techniques to novel and sometimes exclusive subjects. Of course, publishing articles on extremely specialized subjects realistically exposes a journal to the immediate risk of decreasing its impact factor, but this is a chance worth taking.

\section{References}

1. Björk BC, Solomon D. Open access versus subscription journals: a comparison of scientific impact. BMC Medicine 2012; 10:73.

2. Pellicciari C, Malatesta M. Identifying pathological biomarkers: histochemistry still ranks high in the omics era. Eur $\mathrm{J}$ Histochem 2011;55:e42.

3. Pellicciari C. Histochemistry through the years, browsing a long-established journal: novelties in traditional subjects. Eur J Histochem 2010;54:e51.

4. Cortés-Gutiérrez EI, Dávila-Rodríguez MI, Fernández JL, López-Fernández C, Gosálvez J. Koilocytes are enriched for alkaline-labile sites. Eur J Histochem 2010;54:e32.

5. Nemolato S, Cabras T, Fanari MU, Cau F, Fraschini M, Manconi B, et al. Thymosin beta 4 expression in normal skin, colon mucosa and in tumor infiltrating mast cells. Eur J Histochem 2010;54:e3.

6. Perrone G, Morini S, Santini D, Rabitti C, Vincenzi B, Alloni R, et al. Human equilibrative nucleoside transporter 1 and carcinoma of the ampulla of Vater: expression differences in tumour histotypes. Eur J Histochem 2010;54:e38.

7. Ruggeri RM., Vitarelli E, Barresi G, Trimarchi F, Benvenga S, Trovato M. The tyrosine kinase receptor c-met, its cognate ligand HGF and the tyrosine kinase receptor trasducers STAT3, PI3K and RHO in thyroid nodules associated with Hashimoto's thyroiditis: an immunohis- tochemical characterization. Eur J Histochem 2010;54:e24.

8. Salemi M, Calogero AE, Zaccarello G, Castiglione R, Cosentino A, Campagna C, et al. Expression of SPANX proteins in normal prostatic tissue and in prostate cancer. Eur J Histochem 2010;54:e41.

9. Xue J, Chen H, Diao L, Chen X, Xia D. Expression of Caveolin-1 in tongue squamous cell carcinoma by quantum dots. Eur J Histochem 2010;54:e20.

10. Bujas T, Marusic Z, Peric Balja M, Mijic A, Kruslin B, Tomas D. MAGE-A3/4 and NYES0-1 antigens expression in metastatic esophageal squamous cell carcinoma. Eur J Histochem 2011;55:e7.

11. Pilloni L, Bianco P, Difelice E, Cabras S, Castellanos ME, Atzori L, et al. The usefulness of c-Kit in the immunohistochemical assessment of melanocytic lesions. Eur J Histochem 2011;55:e20.

12. Piras F, Ionta MT, Lai S, Perra MT, Atzori F, Minerba L, et al. Nestin expression associates with poor prognosis and triple negative phenotype in locally advanced (T4) breast cancer. Eur J Histochem 2011; 55:e39.

13. Protrka Z, Arsenijevic S, Dimitrijevic A, Mitrovic S, Stankovic V, Milosavljevic M, et al. Co-overexpression of bcl-2 and cmyc in uterine cervix carcinomas and premalignant lesions. Eur J Histochem 2011;55:e8.

14. Galia A, Calogero AE, Condorelli R, Fraggetta F, La Corte A, Ridolfo F, et al. PARP-1 protein expression in glioblastoma multiforme. Eur J Histochem 2012;56:e9.

15. Gurzu S, Krause M, Ember I, Azamfirei L, Gobel G, Feher K, et al. Mena, a new available marker in tumors of salivary glands? Eur J Histochem 2012;56:e8.

16. Artico M, Bronzetti E, Alicino V, B Ionta, Bosco S, Grande C, et al. Human gallbladder carcinoma: Role of neurotrophins, MIB-1, CD34 and CA15-3. Eur J Histochem 2010;54:e10.

17. Artico M, Bronzetti E, Ionta B, Bruno M, Greco A, Ruoppolo G, et al. Reinke's Edema: investigations on the role of MIB1 and hepatocyte growth factor. Eur J Histochem 2010;54:e30.

18. Shen Z, Ren Y, Ye D, Guo J, Kang C, Ding $\mathrm{H}$. Significance and relationship between DJ-1 gene and survivin gene expression in laryngeal carcinoma. Eur J Histochem 2011;55:e9.

19. Song R, Xu W, Chen Y, Li Z, Zeng Y, Fu Y. The expression of Sirtuins 1 and 4 in peripheral blood leukocytes from patients with type 2 diabetes. Eur J Histochem 2011;55:e10. (DOI: 10.4081/ejh.2011.e10)

20. Zhu Y, Ning D, Wang F, Liu C, Xu Y, Jia X, 
et al. Effect of thyroxine on munc-18 and syntaxin-1 expression in dorsal hippocampus of adult-onset hypothyroid rats. Eur J Histochem 2012;56:e22.

21. Nowak D, Mazur AJ, Popow-Woźniak A, Radwańska A, Mannherz HG, MalickaBłaszkiewicz M. Subcellular distribution and expression of cofilin and ezrin in human colon adenocarcinoma cell lines with different metastatic potential. Eur J Histochem 2010;54:e14.

22. Tsirakis G, Pappa CA, Kaparou M, Katsomitrou V, Hatzivasili A, Alegakis T, et al. Assessment of proliferating cell nuclear antigen and its relationship with proinflammatory cytokines and parameters of disease activity in multiple myeloma patients. Eur J Histochem 2011;55:e21.

23. Karaca T, Bayiroglu F, Yoruk MU, Kaya S, Uslu S, Comba B, et al. Effect of royal jelly on experimental colitis Induced by acetic acid and alteration of mast cell distribution in the colon of rats. Eur J Histochem 2010;54:e35.

24. Cenni V, Capanni C, Columbaro M, Ortolani M, D'Apice MR, Novelli G, et al. Autophagic degradation of farnesylated prelamin A as a therapeutic approach to lamin-linked progeria. Eur J Histochem 2011;55:e36.

25. Tomasello G, Sciumé C, Rappa F, Rodolico V, Zerilli M, Martorana A, et al. Hsp10, Hsp70, and Hsp90 immunohistochemical levels change in ulcerative colitis after therapy. Eur J Histochem 2011;55:e38.

26. Asara Y, Marchal JA, Bandiera P, Mazzarello V, Delogu LG, Sotgiu MA, et al. Cadmium influences the 5-Fluorouracil cytotoxic effects on breast cancer cells. Eur J Histochem 2012;56:el.

27. Michalski D, Heindl M, Kacza JH, Laignel F, Küppers-Tiedt L, Schneider D, et al. Spatio-temporal course of macrophagelike cell accumulation after experimental embolic stroke depending on treatment with tissue plasminogen activator and its combination with hyperbaric oxygenation. Eur J Histochem 2012;56:e14.

28. Battistelli S, Citterio B, Baldelli B, Parlani C, Malatesta M. Histochemical and morphometrical study of mouse intestine epithelium after a long term diet containing genetically modified soybean. Eur J Histochem 2010;54:e36.

29. Malatesta M, Meola G. Structural and functional alterations of the cell nucleus in skeletal muscle wasting: the evidence in situ. Eur J Histochem 2010;54:e44.

30. Sbarbati A, Accorsi D, Benati D, Marchetti L, Orsini G, Rigotti G, et al. Subcutaneous adipose tissue classification. Eur J Histochem 2010;54:e48.
31. Malatesta M, Giagnacovo M, Renna LV, Cardani R, Meola G, Pellicciari C. Cultured myoblasts from patients affected by myotonic dystrophy type 2 exhibit senescence-related features: ultrastructural evidence. Eur J Histochem 2011;55:e26.

32. Panettiere P, Accorsi D, Marchetti L, Minicozzi AM, Orsini G, Bernardi P, et al. The trochanteric fat pad. Eur J Histochem 2011;55:e16.

33. Curzi D, Salucci S, Marini M, Esposito F, Agnello L, Veicsteinas A, et al. How physical exercise changes rat myotendinous junctions: an ultrastructural study. Eur J Histochem 2012;56:e19.

34. Escobar Sánchez ML, Echeverría Martínez OM, Vázquez-Nin GH. Immunohistochemical and ultrastructural visualization of different routes of oocyte elimination in adult rats. Eur $\mathrm{J}$ Histochem 2012;56:e17.

35. Khalili MA, Maione M, Palmerini MG, Bianchi S, Macchiarelli G, Nottola SA. Ultrastructure of human mature oocytes after vitrification. Eur $\mathrm{J}$ Histochem 2012;56:e38.

36. Scarsella G, Nebbioso M, Stefanini S, Pescosolido N. Degenerative effects in rat eyes after experimental ocular hypertension. Eur J Histochem 2012;56:e42.

37. Zhao $\mathrm{Y}$, Huang $\mathrm{H}$, Jiang $\mathrm{Y}$, Wei H, Liu $\mathrm{P}$, Wang $\mathrm{W}$, et al. Unusual localization and translocation of TRPV4 protein in cultured ventricular myocytes of the neonatal rat. Eur J Histochem 2012;56:e32.

38. Costanzo M, Cisterna B, Zharskaya 00, Zatsepina OV, Biggiogera M. Discrete foci containing RNAse A are found in nucleoli of HeLa cells after aging in culture. Eur J Histochem 2011;55:e15.

39. Lattanzi G, Marmiroli S, Facchini AQ, Maraldi NM. Nuclear damages and oxidative stress: new perspectives for laminopathies. Eur J Histochem 2012;56: e45.

40. Perdoni F, Malatesta M, Cardani R, Giagnacovo M, Mancinelli E, Meola G, et al. RNA/MBNL1-containing foci in myoblast nuclei from patients affected by myotonic dystrophy type 2 : an immunocytochemical study. Eur J Histochem 2009;53:151-8.

41. Malatesta M, Perdoni F, Muller S, Zancanaro C, Pellicciari C. Nuclei of aged myofibres undergo structural and functional changes suggesting impairment in RNA processing. Eur $\mathrm{J}$ Histochem 2009;53: 97-106.

42. Malatesta M. Skeletal muscle features in myotonic dystrophy and sarcopenia: do similar nuclear mechanisms lead to skeletal muscle wasting? Eur J Histochem 2012;56:e36.

43. Serradifalco C, Catanese P, Rizzuto L, Cappello F, Puleio R, Barresi V, et al. Embryonic and foetal Islet-1 positive cells in human hearts are also positive to c-Kit C. Eur J Histochem 2011;55:e41.

44. Rus A, Del Moral ML, Molina F, Peinado MA. Upregulation of cardiac NO/NOS system during short-term hypoxia and the subsequent reoxygenation period. Eur J Histochem 2011;55:e17.

45. Chiusa M, Timolati F, Perriard JC, Suter TM, Zuppinger C. Sodium nitroprusside induces cell death and cytoskeleton degradation in adult rat cardiomyocytes in vitro: implications for anthracyclineinduced cardiotoxicity. Eur J Histochem 2012; 56:e15.

46. Zara S, Macchi V, De Caro R, Rapino M, Cataldi A, Porzionato A. pPKC $\alpha$ mediatedHIF- $1 \alpha$ activation related to the morphological modifications occurring in neonatal myocardial tissue in response to severe and mild hyperoxia. Eur J Histochem 2012;56:e2.

47. Acosta M, Filippa V, Mohamed F. Folliculostellate cells in pituitary pars distalis of male viscacha: immunohistochemical, morphometric and ultrastructural study. Eur J Histochem 2010;54:e1.

48. Ćirović S, Marković-Lipkovski J, Todorović J, Nešović-0stojić J, Jović M, Ilić $\mathrm{S}$, et al. Differential expression of $\mathrm{KCNQ1} \mathrm{K}+$ channel in tubular cells of frog kidney. Eur J Histochem 2010;54:e7.

49. Kluchova D, Bolekova A, Heichel C, Bron AJ, Kozak I. NADPH-diaphorase expression in the Meibomian glands of rat palpebra in postnatal development. Eur J Histochem 2010;54:e47.

50. Lovasova K, Kluchova D, Bolekova A, Dorko F, Spakovska T. Distribution of NADPH-diaphorase and AChE activity in the anterior leaflet of rat mitral valve. Eur J Histochem 2010;54:e5.

51. Matozzo V, Marin MG. First cytochemical study of haemocytes from the crab Carcinus aestuarii (Crustacea, Decapoda). Eur J Histochem 2010;54:e9.

52. Mignini F, Sabbatini M, D'Andrea V, Cavallotti $C$. Intrinsic innervation and dopaminergic markers after experimental denervation in rat thymus. Eur J Histochem 2010;54:e17.

53. Sandhu MA, Rahman ZU, Riaz A, Rahman SU, Javed I, Ullah N. Somatotrophs and lactotrophs: an immunohistochemical study of Gallus domesticus pituitary gland at different stages of induced moult. Eur J Histochem 2010;54:e25.

54. Bai C, Wang D, Li C, Jin D, Li C, Guan W, et al. Establishment and biological characteristics of a Jingning chicken embry- 
onic fibroblast bank. Eur $\mathrm{J}$ Histochem 2011;55:e4.

55. Hinken M, Halwachs S, Kneuer C, Honscha W. Subcellular localization and distribution of the reduced folate carrier in normal rat tissues. Eur $\mathrm{J}$ Histochem 2011;55:e3.

56. Li Q, Weng J, Zhang H, Lu L, Ma X, Wang $Q$, et al. Immunohistochemical evidence: testicular and scented glandular androgen synthesis in muskrats (Ondatra zibethicus) during the breeding season. Eur J Histochem 2011;55:e32.

57. Nemolato S, Van Eyken P, Cabras T, Cau F, Fanari MU, Locci A, et al. Expression pattern of thymosin beta 4 in the adult human liver. Eur J Histochem 2011;55: e25.

58. Porzionato A, Fenu G, Rucinski M, Macchi $\mathrm{V}$, Montella A, Malendowicz LK, et al. KISS1 and KISS1R expression in the human and rat carotid body and superior cervical ganglion. Eur $\mathrm{J}$ Histochem 2011;55:e14.

59. Sabbatini ARM, Mattii L, Battolla B, Polizzi E, Martini D, Ranieri-Raggi M, et al. Evidence that muscle cells do not express the histidine-rich glycoprotein associated with AMP deaminase but can internalise the plasma protein. Eur $\mathbf{J}$ Histochem 2011;55:e6.

60. Amaroli A, Chessa MG. Detection and characterisation of NAD(P)H-diaphorase activity in Dictyostelium discoideum cells (Protozoa). Eur J Histochem 2012;56:e47.

61. Casini A, Vaccaro R, D'Este L, Sakaue Y, Bellier JP, Kimura H, et al. Immunolocalization of choline acetyltransferase of common type in the central brain mass of Octopus vulgaris. Eur J Histochem 2012; 56:e34.

62. Fukui K, Yasui T, Gomi H, Sugiya H, Fujimori 0, Meyer W, et al. Histochemical localization of sialic acids and antimicrobial substances in eccrine glands of porcine snout skin Eur J Histochem 2012; 56:e6.

63. Kawashima M, Imura K, Sato I. Topographical organization of TRPV1immunoreactive epithelium and CGRPimmunoreactive nerve terminals in rodent tongue. Eur J Histochem 2012;56: e21.

64. Lee HS, Chang JH, Ku SK. An immunohistochemical study of the pancreatic endocrine cells of the Korean golden frog, Rana plancyi chosenica. Eur J Histochem 2012;56:e5.

65. Pennati R, Dell'Anna A, Zega G, De Bernardi F. Immunohistochemical study of the nervous system of the tunicate Thalia democratica (Forsskal, 1775). Eur J Histochem 2012;56:e16.
66. Wang L, Wang J, Zhou X, Li J, Shi Y, Han $Z$, et al. CM2 antigen, a potential novel molecule participating in glucuronide transport on rat hepatocyte canalicular membrane. Eur J Histochem 2012;56:e26.

67. Costa CAX, de Brito KNO, Gomes MA, Caliari MV. Histopathological and immunohistochemical study of the hepatic lesions experimentally induced by Entamoeba dispar. Eur J Histochem 2010; 54:e39.

68. Ferrandino I, Favorito R, Grimaldi MC. Cadmium induces changes on ACTH and PRL cells in Podarcis sicula Lizard pituitary gland. Eur J Histochem 2010;54:e45.

69. Kovšca Janjatovic A, Lacković G, Bozic F, D Kezic, Popovic M, Valpotić H, et al. Histomorphometric evaluation of intestinal cellular immune responses in pigs immunized with live oral F4ac+ nonenterotoxigenic E. coli vaccine against postweaning colibacillosis. Eur J Histochem 2010;54:e4.

70. Valpotić H, Kovšca Janjatović A, Lacković G, Božić F, Dobranić V, Svoboda D, et al. Increased number of intestinal villous $M$ cells in levamisole - pretreated weaned pigs experimentally infected with F4ac+ enterotoxigenic Escherichia coli strain. Eur J Histochem 2010;54:e18.

71. Vatsos IN, Kotzamanis Y, Henry M, Angelidis P, Alexis M. Monitoring stress in fish by applying image analysis to their skin mucous cells. Eur J Histochem 2010;54:e22.

72. Bertone V, Tarantola E, Ferrigno A, Gringeri E, Barni S, Vairetti M, et al. Altered alkaline phosphatase activity in obese Zucker rats liver respect to lean Zucker and Wistar rats discussed in terms of all putative roles ascribed to the enzyme. Eur J Histochem 2011;55:e5.

73. Bolekova A, Spakovska T, Kluchova D, Toth S, Vesela J. NADPH-diaphorase expression in the rat jejunum after intestinal ischemia/reperfusion. Eur J Histochem 2011;55:e23.

74. Dorko F, Danko J, Flešárová $S$, Boroš E, Sobeková A. Effect of pesticide bendiocarbamate on distribution of acetylcholineand butyrylcholine-positive nerves in rabbit's thymus. Eur J Histochem 2011;55: e37.

75. Nara T, Yasui T, Fujimori 0, Meyer W, Tsukise A. Histochemical properties of sialic acids and antimicrobial substances in canine anal glands. Eur J Histochem 2011;55:e29.

76. Kopera I, Durlej M, Hejmej A, KnapczykStwora K, Duda M, Slomczynska M, et al. Effects of pre- and postnatal exposure to flutamide on connexin 43 expression in testes and ovaries of prepubertal pigs. Eur
J Histochem 2010;54:e15.

77. Nemolato S, Cabras T, Fanari MU, Cau F, Fanni D, Gerosa C, et al. Immunoreactivity of thymosin beta 4 in human foetal and adult genitourinary tract. Eur J Histochem 2010;54:e43.

78. Luciano AM, Corbani D, Lodde V, Tessaro I, Franciosi F, Peluso JJ, et al. Expression of progesterone receptor membrane component-1 in bovine reproductive system during estrous cycle. Eur J Histochem 2011;55:e27.

79. Luciano AM, Lodde V, Franciosi F, Tessaro I, Corbani D, Modina S. Large-scale chromatin morpho-functional changes during mammalian oocyte growth and differentiation. Eur J Histochem 2012;56:e37.

80. Fanni D, Iacovidou N, Locci A, Gerosa C, Nemolato S, Van Eyken P, et al. MUC1 marks collecting tubules, renal vesicles, comma- and S-shaped bodies in human developing kidney tubules, renal vesicles, comma- and s-shaped bodies in human kidney. Eur J Histochem 2012;56:e40.

81. Godoy-Guzmán C, San Martin S, Pereda J. Proteoglycan and collagen expression during human air conducting system development. Eur J Histochem 2012;56: e29.

82. Aita M, Benedetti F, Carafelli E, Caccia E, Romano N. Effects of hypophyseal or thymic allograft on thymus development in partially decerebrate chicken embryos: expression of PCNA and CD3 markers. Eur J Histochem 2010;54:e37.

83. Lacunza E, Ferretti V, Barbeito C, SegalEiras A, Croce MV. Immunohistochemical evidence of Mucl expression during rat embryonic development. Eur J Histochem 2010;54:e49.

84. Lorenzi T, Turi A, Crescimanno C, Morroni M, Castellucci M, David G, et al. Syndecan expressions in the human amnion and chorionic plate. Eur J Histochem 2010;54:e42.

85. Radaelli G, Poltronieri C, Simontacchi C, Negrato E, Pascoli F, Libertini A, et al. Immunohistochemical localization of IGFI, IGF-II and MSTN proteins during development of triploid sea bass (Dicentrarchus labrax). Eur J Histochem 2010;54:e16.

86. Shibata S, Fukuoka H, Sato R, Abe T, Suzuki Y. An in situ hybridization study of the insulin-like growth factor system in developing condylar cartilage of the fetal mouse mandible. Eur J Histochem 2012; 56:e23.

87. He S, Yang J. Maturation of neurotransmission in the developing rat cochlea: immunohistochemical evidence from differential expression of synaptophysin and synaptobrevin 2. Eur J Histochem 2011; 
55:e2.

88. Lievajova K, Blasko J, Martoncikova M, Cigankova V, Racekova E. Delayed maturation and altered proliferation within the rat rostral migratory stream following maternal deprivation. Eur J Histochem 2011;55:e33.

89. Anwar H, Rahman ZU, Muhammad F, Javed I. Immunohistochemical localization and morphometry of somatotrophs and lactotrophs in protein, probiotic and symbiotic supplemented molted layers. Eur J Histochem 2012;56:e28.

90. Dorko F, Kluchová D, Boleková A, Lovasová K, Špakovská T, Borošová T. Influence of surgical and chemical orchidectomy on weight and distribution of AChE-nerve fibres in thymuses of adult rats. Eur J Histochem 2011;55:e22.

91. Oboti L, Peretto P, De Marchis S, Fasolo A. From chemical neuroanatomy to an understanding of the olfactory system. Eur J Histochem 2011;55:e35.

92. Kovsca Janjatovic A, Valpotic H, Kezic D, Lacković G, Gregorovic G, Sladoljev S, et al. Secretion of immunomodulating neuropeptides (VIP, SP) and nitric oxide synthase in porcine small intestine during postnatal development. Eur J Histochem 2012;56:e30.

93. Lomoio S, Necchi D, Scherini E. Uneven distribution of NG2 cells in the rat cerebellar vermis and changes in aging. Eur $\mathrm{J}$ Histochem 2012;56:e27.

94. Musumeci G, Loreto C, Carnazza ML, F Coppolino, Cardile V, Leonardi R. Lubricin is expressed in chondrocytes derived from osteoarthritic cartilage encapsulated in poly(ethylene glycol) diacrylate scaffold. Eur J Histochem 2011;55:e31.

95. Narducci P, Bortul R, Bareggi R, Nicolin V. Clathrin-dependent endocytosis of membrane-bound RANKL in differentiated osteoclasts. Eur J Histochem 2010;54:e6.

96. Riccio M, Resca E, Maraldi T, Pisciotta A, Ferrari A, Bruzzesi G, et al. Human dental pulp stem cells produce mineralized matrix in 2D and 3D cultures. Eur J Histochem 2010; 54:e46.

97. Loreto C, Almeida LE, Migliore MR, Caltabiano M, Leonardi R. TRAIL, DR5 and caspase 3-dependent apoptosis in vessels of diseased human temporomandibular joint disc. An immunohistochemical study. Eur J Histochem 2010;54:e40.

98. Boncompagni E, Gini E, Ferrigno A, Milanesi G, Gringeri E, Barni S, et al. Decreased apoptosis in fatty livers submitted to subnormothermic machine-perfusion respect to cold storage. Eur J Histochem 2011;55:e40.

99. Markelic M, Velickovic K, Golic I, Otasevic
V, Stancic A, Jankovic A, et al. Endothelial cell apoptosis in brown adipose tissue of rats induced by hyperinsulinaemia: the possible role of TNF- $\alpha$. Eur J Histochem 2011;55:e34.

100. Stępiński D. Immunofluorescent localization of ubiquitin and proteasomes in nucleolar vacuoles of soybean root meristematic cells. Eur J Histochem 2012;56:e13.

101. Kiga N, Tojyo I, Matsumoto T, Hiraishi Y, Shinohara Y, Fujita S. Expression of lumican related to CD34 and VEGF in the articular disc of the human temporomandibular joint. Eur J Histochem 2010;54:e34.

102. Matsumoto T, Inayama M, Tojyo I, Kiga N, Fujita S. Expression of hyaluronan synthase 3 in deformed human temporomandibular joint discs: in vivo and in vitro studies. Eur $\mathrm{J}$ Histochem 2010;54:e50.

103. Nicolin V, Dal Piaz F, Nori SL, Narducci P, De Tommasi N. Inhibition of bone resorption by Tanshinone VI isolated from Salvia miltiorrhiza Bunge. Eur J Histochem 2010;54:e21.

104. de Moraes LOC, Lodi FR, Gomes TS, Oshima CTF, Marques SR, Lancellotti CLP, et al. Immunohistochemical expression of types I and III collagen antibodies in the temporomandibular joint disc of human foetuses. Eur J Histochem 2011;55:e24.

105. Kiga N, Tojyo I, Matsumoto T, Hiraishi Y, Shinohara Y, Makino S, et al. Expression of lumican and fibromodulin following interleukin-1 beta stimulation of disc cells of the human temporomandibular joint. Eur J Histochem 2011;55:e11.

106. Bradaschia-Correa V, Barrence FAC, Ferreira LB, Massa LF, Arana-Chavez VE. Effect of alendronate on endochondral ossification in mandibular condyles of growing rats. Eur J Histochem 2012; 56:e24.

107. Carvalho-Filho EP, Stabile AC, Ervolino E, Stuani MBS, Iyomasa MM, Rocha MJA. Celecoxib treatment does not alter recruitment and activation of osteoclasts in the initial phase of experimental tooth movement. Eur J Histochem 2012;56:e43.

108. Damico JP, Ervolino E, Torres KR, Batagello DS, Cruz-Rizzolo RJ, Casatti $\mathrm{CA}$, et al. Phenotypic alterations of neuropeptide $\mathrm{Y}$ and calcitonin gene-related peptide-containing neurons innervating the rat temporomandibular joint during carrageenan-induced arthritis. Eur J Histochem 2012;56:e31.

109. Kiga N. Histochemistry for studying structure and function of the articular disc of the human temporomandibular joint. Eur J Histochem 2012;56:e11.

110. Proceedings of the XXXI National Meeting of the Italian Society for the Study of Connective Tissues (SISC). Varese, 27-28 October 2011, Italy. Eur J Histochem 2011;55(Suppl.2). DOI: 10.4081/2011.2s.

111. Proceedings of the XXXII National Meeting of the Italian Society for the Study of Connective Tissues (SISC). Bologna, 20-21 October 2012, Italy. Eur J Histochem 2012;56(Suppl.2). DOI: 10.4081/2012.1s.

112. Galbo T, Pedersen IL, Fløyel T, BangBerthelsen CH, Serup P, Madsen OD, et al. Novel monoclonal antibodies against Pdx1 reveal feedback regulation of Pdx1 protein levels. Eur J Histochem 2010;54:e19.

113. Giagnacovo M, Cardani R, Meola G, Pellicciari C, Malatesta M. Routinely frozen biopsies of human skeletal muscle are suitable for morphological and immunocytochemical analyses at transmission electron microscopy. Eur J Histochem 2010;54:e31.

114. Boschi F, Fontanella M, Calderan L, Sbarbati A. Luminescence and fluorescence of essential oils. Fluorescence imaging in vivo of wild chamomile oil. Eur J Histochem 2011;55:e18.

115. Fassina L, Magenes G, Inzaghi A, Palumbo S, Allavena G, Miracco C, et al. AUTOCOUNTER, an ImageJ JavaScript to analyze LC3B-GFP expression dynamics in autophagy-induced astrocytoma cells. Eur J Histochem 2012;56:e44.

116. Giansanti V, Santamaria G, Torriglia A, Aredia F, Scovassi AI, Bottiroli G, et al. Fluorescence properties of the $\mathrm{Na}+\mathrm{H}+$ exchanger inhibitor HMA (5(N,N-hexamethylene)amiloride) are modulated by intracellular $\mathrm{pH}$. Eur J Histochem 2012;56:e3.)

117. Malatesta M, Giagnacovo M, Costanzo M, Conti B, Genta I, Dorati R, et al. Diaminobenzidine photoconversion is a suitable tool for tracking the intracellular location of fluorescently labelled nanoparticles at transmission electron microscopy. Eur J Histochem 2012;56:e20.

118. Petr T, Šmíd V, Šmídová J, Hůlková H, Jirkovská M, Elleder M, et al. Histochemical detection of GM1 ganglioside using cholera toxin-B subunit. Evaluation of critical factors optimal for in situ detection with special emphasis to acetone pre-extraction. Eur J Histochem 2010;54:e23.

119. Relucenti M, Heyn R, Petruzziello L, Pugliese G, Taurino M, Familiari G. Detecting microcalcifications in atherosclerotic plaques by a simple trichromic staining method for epoxy embedded carotid endarterectomize. Eur J Histochem 2010;54:e33. 
120. Sawai H, Domae N. Transfer of Fas (CD95) protein from the cell surface to the surface of polystyrene beads coated with anti-Fas antibody clone $\mathrm{CH}-11$. Eur J Histochem 2010;54:e8.

121. Dávila-Rodríguez MI, Cortés-Gutiérrez Elva I, Cerda Flores RM, Pita M, Fernández JL, López-Fernández $\mathrm{C}$, et al. Constitutive heterochromatin polymorphisms in human chromosomes identified by whole comparative genomic hybridization. Eur J Histochem 2011; 55:e28.

122. Galvão MJ, Santos A, Ribeiro MD, Ferreira A, Nolasco F. Optimization of the tartrateresistant acid phosphatase detection by histochemical method. Eur J Histochem 2011;55:e1.

123. Benerini Gatta L, Cadei M, Balzarini P, Castriciano S, Paroni R, Verzeletti AL, et al. Application of alternative fixatives to formalin in diagnostic pathology. Eur $\mathrm{J}$ Histochem 2012;56:e12.

124. Bottone MG, Santin G, Soldani C, Veneroni P, Scovassi AI, Alpini C. Intracellular distribution of Tankyrases as detected by multicolor immunofluorescence techniques. Eur $\mathrm{J}$ Histochem 2012;56:e4.

125. Gosalvez J, Crespo F, Vega-Pla JL, LópezFernández C, Cortés-Gutiérrez EI, Mezzanotte R. Shared Y chromosome repetitive DNA sequences in stallion and donkey as visualized using whole-genomic comparative hybridization. Eur J Histochem 2010;54:e2.

126. Coluccia E, Pichiri G, Nieddu M, Coni P, Manconi S, Deiana AM, et al. Identification of two new repetitive elements and chromosomal mapping of repetitive DNA sequences in the fish Gymnothorax unicolor (Anguilliformes: Muraenidae). Eur J Histochem 2011;55 :e12.

127. Huebner S, Efthymiadis A. Recent progress in histochemistry and cell biology. Histochem Cell Biol 2012;137:403-57. 